\title{
oren @acerss
}

\section{International Journal of Applied Sciences and Biotechnology}

\author{
A Rapid Publishing Journal
}

ISSN 2091-2609

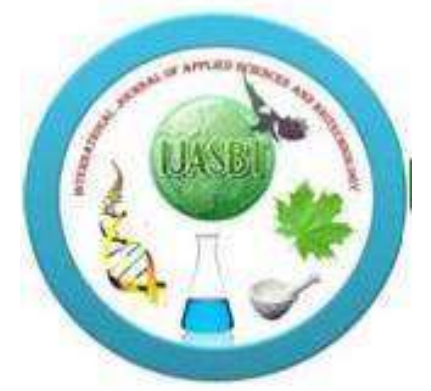

Available online at:

$\frac{\text { http://www.ijasbt.org }}{\&}$

http://www.nepjol.info/index.php/IJASBT/index

\section{Indexing and Abstracting}

CrossRef, Google Scholar, Global Impact Factor, Genamics, Index Copernicus, Directory of Open Access Journals, WorldCat, Electronic Journals Library (EZB), Universitätsbibliothek Leipzig, Hamburg University, UTS (University of Technology, Sydney): Library, International Society of Universal Research in Sciences (EyeSource), Journal Seeker, WZB, Socolar, BioRes, Indian Science, Jadoun Science, Jour-Informatics, Journal Directory, JournalTOCs, Academic Journals Database, Journal Quality Evaluation Report, PDOAJ, Science Central, Journal Impact Factor, NewJour, Open Science Directory, Directory of Research Journals Indexing, Open Access Library, International Impact Factor Services, SciSeek, Cabell's Directories, Scientific Indexing Services, CiteFactor, UniSA Library, InfoBase Index, Infomine, Getinfo, Open Academic Journals Index, HINARI, etc.

\section{CODEN (Chemical Abstract Services, USA): IJASKD}

Vol-2(4) December, 2014

Impact factor*: $\mathbf{1 . 4 2 2}$

Scientific Journal Impact factor $\#$ : 3.419

SEM-Biotech Index Copernicus Value: $\mathbf{6 . 0 2}$

Publishing

*Impact factor is issued by Universal Impact Factor. Kindly note that this is not the IF of Journal Citation Report (JCR). "Impact factor is issued by SJIF INNO SPACE. 


\title{
Research Article
}

\section{EFFECT OF CARBON SOURCES ON THE BIOMASS BUILD-UP AND DEGRADATION OF RUBBER PROCESSING INDUSTRY EFFLUENT}

\author{
K. Girish \\ Postgraduate Department of Microbiology, Maharani's Science College for Women, JLB Road, Mysore - 570 005, Karnataka, India \\ Corresponding author email: girishk77@yahoo.com
}

\begin{abstract}
Rubber processing industry effluent represents a serious environmental pollution problem especially for underground and surface water. Wastewater collected from rubber processing industry was characterized for their pollution characteristics. Analysis showed that the biological oxygen demand (BOD), chemical oxygen demand (COD), total dissolved solids (TDS), total suspended solids (TSS), total solids (TS), ammonia and phosphate were high when compared to effluent discharge standard for industrial wastewater. Four bacterial species were isolated from the wastes and were identified as Arthrobacter sp., Bacillus sp., Lactobacillus sp., and Pseudomonas sp. A bacterial consortium was constituted by mixing proportionately these four bacteria and used in effluent aerobic biotreatment. Complex carbon sources such as bagasse, corn-cob, rice straw, wheat bran, molasses, corn steep liquor, were screened for their effect on growth of the consortium constituted. Highest biomass production was in molasses followed by rice straw hydrolysate, wheat bran hydrolysate and bagasse hydrolysate. However, the inoculum grown on rice straw and wheat bran hydrolysate caused maximum degradation in terms of reduction in various parameters such as BOD, COD, TDS, TSS, $\mathrm{NH}_{4}{ }^{+}$and $\mathrm{PO}_{4}{ }^{3}$, about 70 to $80 \%$ reduction was observed. From the results of the present study it could be inferred that the constituted consortium could effectively be used for the treatment of effluents from rubber processing industry and rice straw and wheat bran hydrolysate could be used for mass production of effective consortium.
\end{abstract}

Key words: Rubber processing industry; Effluent; Bacterial consortium; Carbon sources; Biological treatment; Biodegradation.

\section{Introduction}

Rubber processing industry is one of the important industries which produce raw materials used for the manufacture of rubber industrial products (conveyor belts, rubber rollers, etc.), automotive products (fan belts, radiator hoses, etc.), latex products (rubber gloves, toys hygienic products, etc.) and many kinds of adhesives. The major users of natural rubber are tire and footwear industries (Anon, 2007). This processing of natural rubber causes many environmental impacts including air and water pollution (Tekasakul and Tekasakul, 2006). The production of rubber products from natural rubber needs large amount of water for its operation producing large quantities of effluent (Leong et al., 2003; Rungruang and Babel, 2008). The disposal of these effluents into surface waters - wells, streams, lakes or even the sea without any treatment can give rise to serious depletion of dissolved oxygen, thus affecting the normal environment supporting the aquatic system (Mohammadi et al., 2010). The high level of phosphate and ammonia in rubber effluent makes it a good medium for algal growth and can result in eutrophication of surface waters if discharged without proper treatment (Iyagba et al., 2008). The high level of hydrogen sulphide $\left(\mathrm{H}_{2} \mathrm{~S}\right)$ is another problem that causes malodor problems and makes water unpalatable (Rungruang and Babel, 2008).
The increasing global concern on the environment demands that wastes should be properly managed in order to minimize and possibly eliminate their potential harm to public health and the environment (Asia and Akporhonor, 2007). Though several methods have been described in the scientific literatures for industrial effluent treatment, microbes have been drawing tremendous attention in recent years due to their ability to degrade waste materials and thereby improving water quality (Boominathan et al., 2007). Owing to the need of biological treatment of rubber industry wastes, indigenous bacteria that can readily degrade the rubber wastes present in the effluents were isolated. Rubber and effluents from rubber processing support microbial growth and has been reported by a number of workers (Mahat and MacRae, 1992; Atagana et al., 1999 a \& b). Since the effluent has limited substrates for microbial growth the biomass build up is low and not sufficient for effective biodegradation. Thus the present study aimed to characterize the effective carbon sources and optimize the inoculum preparation without loss in biodegradative ability. 


\section{Materials and Methods}

\section{Sample collection}

The wastewater was collected from the discharge unit of the rubber processing sewage system in a can which had been thoroughly washed and rinsed with water. The wastewater sample used for DO (dissolved oxygen) and BOD (biological oxygen demand) determinations were collected directly into dark DO bottles and were added some drops of manganous sulphate solution to fix the dissolved oxygen. Samples were collected by lowering the sterile bottle by means of a string into the tank and covered with the screw cap thereafter. The samples were stored at a temperature of $4^{0} \mathrm{C}$ until required (usually between 24 and $48 \mathrm{~h}$ ). The effluents were collected from five different points on the processing - aeration tank, settling tank, backwashed effluent, holding tank and sludge.

\section{Isolation of biodegrading microorganisms}

Nutrient agar (Himedia, India) medium was prepared and sterilized in an autoclave. The molten nutrient agar media was poured (approximately $15 \mathrm{ml}$ ) into each sterilized Petri plates, and allowed to solidify. The effluent was serially diluted up to $10^{-6}$ dilution and $0.1 \mathrm{ml}$ of sample from each dilution was inoculated on solidified agar media and was spread uniformly with the sterile spreader. These Petri plates were incubated in an incubator for $24-48 \mathrm{~h}$ at $30^{\circ} \mathrm{C}$. The Petri plates were observed after incubation for various bacterial colonies. The colony characteristics such as colour, margin, elevation were noted. Four colonies showing distinct colony characteristics were selected and pure cultured on nutrient agar medium.

\section{Identification of bacteria}

The cultures were identified by standard procedures such as morphology, and biochemical characteristics as given by Bergey's Manual of Determinative Bacteriology (Buchanan and Gibbons, 1984). The physiological and biochemical tests were conducted following the methods as described by Cappuccino and Sherman (1999) to identify the bacteria.

\section{Pure culture}

To prepare inoculum, the cultures were grown at $30^{\circ} \mathrm{C}$ on a rotary shaker operating at approximately $120 \mathrm{rpm}$ in the inorganic salts medium amended with $10 \%$ effluent and harvested in early stationary phase by centrifugation at $4^{\circ} \mathrm{C}$. The pellets were washed, the cells were resuspended in buffer, and the entire centrifugation and washing procedure was repeated. The final pellet was resuspended in inorganic salts solution.

\section{Acclimatization}

Microbial consortium was obtained by mixing proportionately all the four bacterial cultures isolated viz., Arthrobacter sp., Bacillus sp., Lactobacillus sp., and Pseudomonas sp. The consortium was acclimatized by growing it in minimal organic salts medium amended with
$10 \%$ of rubber processing industry effluent for $72 \mathrm{~h}$. The minimal medium used in degradation studies contained $(\mathrm{mg}$ / ml) $\mathrm{KH}_{2} \mathrm{PO}_{4}-0.675 ; \mathrm{Na}_{2} \mathrm{HPO}_{4}-5.455 ; \mathrm{NH}_{4} \mathrm{NO}_{3}-0.25$; $\mathrm{MgSO}_{4}-0.2 ; \mathrm{Ca}\left(\mathrm{NO}_{3}\right)_{2}-0.1$; and $1 \mathrm{ml}$ mineral solution.

\section{Optimization of the carbon sources for the large scale production of bacterial consortium}

Complex carbon sources such as Bagasse (juice extracted sugarcane stem), Corn-cob, Rice straw, Wheat bran, Molasses, Corn steep liquor, were used as co-substrates for biomass build-up. Extract of rice straw was prepared by cooking finely powdered rice straw in de-ionized water at 1:50 ratio for $5 \mathrm{~min}$ with constant stirring. The extract obtained was neutralized with $\mathrm{NaOH}$ and centrifuged and the supernatant was collected. For hydrolysates of wheat bran, corn-cob, bagasse and rice straw, $6 \mathrm{~N} \mathrm{H}_{2} \mathrm{SO}_{4}$ was used instead of water.

To study the effect of co-substrates on biomass build-up, co-substrates were added at $1.5 \%$ sugar level (as glucose estimated by phenol sulphuric acid method) to minimal medium along with effluent at $10 \%$. The consortium was inoculated to these flasks and incubated for $72 \mathrm{~h}$. The cells were harvested by centrifugation at $10,000 \mathrm{~g}$ for $10 \mathrm{~min}$ and washed with sterile minimal salts medium. Growth was estimated as protein following Lowry's method and biomass yield was expressed as $\mu \mathrm{g}$ protein $/ \mathrm{ml}$.

\section{Degradation of effluent by the consortium grown on different co-substrates}

Various parameters such as biological oxygen demand (BOD), chemical oxygen demand (COD), total suspended solids (TSS), total dissolved solids (TDS), ammonia $\left(\mathrm{NH}_{4}{ }^{+}\right)$ and phosphate $\left(\mathrm{PO}_{4}{ }^{3-}\right)$ were assayed using standard protocols (APHA, 1995). The effluent was inoculated with $5 \%$ inoculum and incubated for 15 days, and estimation was done at the interval of five days.

\section{Results}

\section{Isolation and Identification of bacteria}

Based on the colony characteristics, staining, motility and many biochemical characteristics the bacteria were identified as Arthrobacter sp., Bacillus sp., Lactobacillus sp., and Pseudomonas sp. The identification was confirmed through the results of number of biochemical tests as mentioned in table 1 .

\section{Optimization of the carbon sources for the large scale production of bacterial consortium}

Molasses supported maximum growth of the consortium followed by rice straw hydrolysate, wheat bran hydrolysate and bagasse hydrolysate. Rice straw extract, corn-cob hydrolysate and corn steep liquor did not support much growth in comparison (Table 2). Molasses, rice straw hydrolysate, wheat bran hydrolysate and bagasse hydrolysate which supported good microbial growth were selected for further experiments. 
Table 1: Characteristics of bacteria used for their identification

\begin{tabular}{|c|c|c|c|c|c|}
\hline $\begin{array}{l}\text { Sl. } \\
\text { No. }\end{array}$ & Characteristics & Arthrobacter sp.* & Bacillus sp. & Lactobacillus sp. & Pseudomonas sp. \\
\hline 1. & Cell shape & $\begin{array}{l}\text { irregular rods with clubbed } \\
\text { ends }\end{array}$ & Rod shaped & Rod shaped & Rod shaped \\
\hline 2. & Gram staining & $\begin{array}{l}\text { Gram positive but could be } \\
\text { decolorized }\end{array}$ & Gram positive & Gram positive & Gram negative \\
\hline 3. & Colony on media & $\begin{array}{l}\text { Colonies on medium were } \\
\text { yellow, round, smooth, } \\
\text { convex and } 0.5 \text { to } 2 \mathrm{~mm} \text { in } \\
\text { diameter }\end{array}$ & $\begin{array}{l}\text { Rough, white, } \\
\text { irregular, flat } \\
\text { colonies, } 2 \text { - } 5 \mathrm{~mm}\end{array}$ & $\begin{array}{l}\text { Convex, entire, } \\
\text { opaque, no pigment, } \\
2-5 \mathrm{~mm}\end{array}$ & $\begin{array}{l}\text { Yellow-greenish colonies, } \\
\text { round to slightly irregular, } \\
\text { smooth, and } 0.5 \text { to } 2 \mathrm{~mm} \text { in } \\
\text { diameter }\end{array}$ \\
\hline 4. & Motility & + & $\begin{array}{l}\text { Motile by } \\
\text { peritrichous } \\
\text { flagella }\end{array}$ & Non-motile & motile with a polar flagellum \\
\hline 5. & Spore & -- & endospore & -- & -- \\
\hline 6. & Catalase & + & + & -- & + \\
\hline 7. & Oxidase & + & + & -- & + \\
\hline 8. & Starch hydrolysis & + & + & -- & -- \\
\hline 9. & Fermentation & No acid, No gas & Acid & $\begin{array}{l}\text { Lactose to lactic acid } \\
\& \mathrm{CO}_{2}\end{array}$ & No acid, No gas \\
\hline 10. & Indole test & -- & -- & -- & -- \\
\hline 11. & Methyl red test & -- & + & + & -- \\
\hline 12. & $\begin{array}{l}\text { Voges-Proskauer } \\
\text { test }\end{array}$ & -- & -- & -- & -- \\
\hline 13. & $\begin{array}{l}\text { Citrate utilization } \\
\text { test }\end{array}$ & -- & -- & -- & + \\
\hline 14. & $\begin{array}{l}\mathrm{H}_{2} \mathrm{~S} \text { production } \\
\text { test }\end{array}$ & -- & -- & -- & -- \\
\hline 15. & Urea hydrolysis & -- & -- & -- & -- \\
\hline 16. & Nitrate reduction & -- & + & -- & -- \\
\hline 17. & Gelatin hydrolysis & + & + & -- & + \\
\hline
\end{tabular}

*Arthrobacter sp.: In young cultures, cells were irregular rods with clubbed ends, whereas in older colonies cocci cells could be observed arranged singly, in pairs and in irregular clumps - characteristic of Arthrobacter species.

Table 2. Biomass yield of consortium after $72 \mathrm{~h}$ growth on different co-substrates (at $1.5 \%$ sugar level)

\begin{tabular}{|l|c|}
\hline \multicolumn{1}{|c|}{ Carbon source (Co-substrates) } & Biomass yield \\
\hline Inoculum & $25 \pm 0.48$ \\
\hline Bagasse hydrolysate & $254 \pm 0.73$ \\
\hline Corn-cob hydrolysate & $81 \pm 0.59$ \\
\hline Rice straw extract & $149 \pm 0.77$ \\
\hline Rice straw hydrolysate & $366 \pm 0.75$ \\
\hline Wheat bran hydrolysate & $304 \pm 0.86$ \\
\hline Molasses & $452 \pm 0.59$ \\
\hline Corn steep liquor & $65 \pm 0.37$ \\
\hline
\end{tabular}


Table 3: Degradation of effluent by the consortium grown with different co-substrates (after 15 days of Incubation)

\begin{tabular}{|l|c|c|c|c|c|}
\hline \multicolumn{1}{|c|}{ Parameters } & $\begin{array}{c}\text { Before } \\
\text { treatment }\end{array}$ & Molasses & $\begin{array}{c}\text { Rice straw } \\
\text { hydrolysate, }\end{array}$ & $\begin{array}{c}\text { Wheat bran } \\
\text { hydrolysate }\end{array}$ & $\begin{array}{c}\text { Bagasse } \\
\text { hydrolysate }\end{array}$ \\
\cline { 3 - 6 } TDS (mg / l) & $2397 \pm 2.38$ & $1243 \pm 2.78$ & $734 \pm 1.80$ & $716 \pm 1.85$ & $1385 \pm 2.38$ \\
\hline TSS (mg / l) & $3734 \pm 4.46$ & $1556 \pm 3.51$ & $879 \pm 1.12$ & $865 \pm 2.70$ & $1655 \pm 3.31$ \\
\hline TS (mg / l) & 6131 & 2799 & 1655 & 1599 & 3040 \\
\hline Ammonia (mg / l) & $118 \pm 1.78$ & $57 \pm 0.86$ & $35 \pm 0.57$ & $32 \pm 0.26$ & $64 \pm 0.86$ \\
\hline Phosphate (mg / l) & $57 \pm 0.89$ & $38 \pm 1.10$ & $21 \pm 0.91$ & $17 \pm 0.34$ & $43 \pm 0.65$ \\
\hline BOD (mg / l) & $1486 \pm 3.31$ & $638 \pm 1.72$ & $424 \pm 1.85$ & $391 \pm 1.72$ & $651 \pm 1.80$ \\
\hline COD (mg / l) & $2961 \pm 2.53$ & $1139 \pm 1.72$ & $652 \pm 1.78$ & $596 \pm 1.12$ & $1198 \pm 1.85$ \\
\hline
\end{tabular}

Values are the mean of three replicates \pm SE

\section{Degradation of effluent by the consortium grown on different co-substrates}

Though molasses supported good growth of consortium, did not show maximum degradation. The consortium grown on rice straw and wheat bran hydrolysate caused maximum degradation (In terms of reduction in BOD, COD, TDS, TSS, $\mathrm{NH}_{4}{ }^{+}$and $\mathrm{PO}_{4}{ }^{3}-$ about $70-80 \%$ reduction was observed) (Table 3). In comparison to the initial levels, both BOD and COD decreased significantly indicating the decrease in the pollutants level. The decrease in the level of chemical oxygen demand indicates the reduction of biologically oxidizable and inert organic materials as a result of the degradation by the bacterial consortium. In comparison to the initial levels substantial reduction in the TDS, TSS, ammonia and phosphate were observed after treatment signifying the degradation of toxic solid components in the effluent by the consortium (Table 3 ). Reduction in ammonia and phosphate levels indicates that the bacteria and the consortium degrade organic and inorganic constituents. Thus rice straw and wheat bran hydrolysate could be used for mass production of effective consortium.

\section{Discussion}

Wastewater is an unavoidable by-product of rubber processing: whatever processing procedures are used for preparing products from latex (Rungruang and Babel, 2008). Rubber processing industries effluent is very toxic and contain strong colour, a large amount of suspended solids, a highly fluctuating $\mathrm{pH}$, high temperature, COD, BOD etc (Asia and Akporhonor, 2007; Mohammadi et al., 2010). Thus treatment of rubber wastewater is a must before it is being disposed to natural water system (Atagana et al., 1999b; Iyagba et al., 2008). Most environmentally friendly process for effluent treatment is biodegradation utilizing indigenous microorganisms for the degradation of complex organic matter into simpler ones (Kumar et al., 2011). In this study the bacterial consortium employed was isolated from the rubber effluents itself. Rubber and effluents from rubber processing are known to support microbial growth (Bode et al., 2001; Cherian and Jayachandran, 2009).

Since a limited quantity of effluent can be used as substrate for inoculum development and acclimatization, the biomass build up is low and not enough for effective biodegradation. Hence it is imperative to use other easily utilizable carbon sources as co-substrates to have good amount of inoculum. In the present study various carbon sources were screened and molasses was found to support better microbial growth followed by rice straw hydrolysate, wheat bran hydrolysate and bagasse hydrolysate. The inoculum grown in these substrates were further employed for biodegradation studies wherein molasses and bagasse hydrolysate grown inoculum did not show maximum degradation, but the consortium grown on rice straw and wheat bran hydrolysate caused maximum degradation.

Analysis results showed that all the effluents had higher BOD and COD values than the permissible limits. Wastes containing high BOD and COD are responsible for a heavy depletion of oxygen levels in the particular sector of the stream or soil (Tariq et al., 2006). Therefore, these effluents needed further elimination of BOD and COD through proper treatment methods before discharge. It is well known that wastewater from industries contain suspended solids, reduced oxygen, inorganic compounds. In order to minimize the environmental and health hazards, these pollutants need to be brought down to permissible limits for safe disposal of waste water (Manju et al., 1998). In the present study, treatment of effluent with bacterial consortium grown on rice straw and wheat bran hydrolysate resulted in a successful reduction of BOD, COD, TDS, TSS, $\mathrm{NH}_{4}{ }^{+}$and $\mathrm{PO}_{4}{ }^{3}$ to a level of about $70-80 \%$. This is a significant reduction enough to make the effluent ready to be discharged into the environment. Rubber effluent consists of high level of $\mathrm{NH}_{4}{ }^{+}$and $\mathrm{PO}_{4}{ }^{3-}$ making it a good medium for algal growth. Any treatment system that 
reduces or eliminates the level of $\mathrm{NH}_{4}{ }^{+}$and $\mathrm{PO}_{4}{ }^{3-}$ compounds in the industrial effluent is a highly effective one (Ye et al., 1988), as this reduces the risk of eutrophication of surface waters. Microbial treatment is also reported to reduce the levels of total suspended solids (TSS) and total dissolve solids (TDS) of industrial effluents (Arun et al., 2004; Monica et al., 2011), as observed in the present study.

\section{Conclusion}

The present investigations were carried out to isolate a few indigenous bacteria that could be used for treatment of rubber processing industry waste, and also to identify a cheap carbon source for large scale production of these bacteria to have enough bacterial inoculum for treatment. The results of present investigations suggest that the consortium isolated from rubber processing industry effluent could be employed for the biodegradation of rubber processing industry effluent, and the rice straw and wheat bran hydrolysate could be employed for good biomass build-up of effective inoculum. Further research is needed to understand the biodegradation ability of each bacteria and synergism among different combination. Molecular characterization for precise identification needs to be carried out.

\section{Acknowledgements}

The authors thank University Grants Commission (UGC), New Delhi for financial support [MRP(S) - 277/08-09/ KAMY004/ UGC- SWRO Dt: 30-Mar-09].

\section{References}

Anononymous (2007) Waste abatement and management in natural rubber processing sector. Asian Institute of Technology School of Environment, Resources and Development. Available from: www.albuw.ait.ac.th/Groups/Assignment/II/Group03.pdf

APHA (1995) Standard method for the examination of water and wastewater, 19th ed. American Water Work Association and Water Environment Federation, Washington D.C.

Arun A, Uma Maheshwari P and Thillai K (2004) Biodegradation of tannery effluent by using tannery effluent isolate. In: Arvind Kumar (ed) Environmental contamination and bioreclamation. APH Publishing Co., New Delhi, 451453.

Asia IO and Akporhonor EE (2007) Characterization and physicochemical treatment of wastewater from rubber processing factory. International Journal of Physical Sciences, 2: 61-67.

Atagana HI, Ejechi BO and Ayilumo AM (1999a) Fungi associated with degradation of wastes from rubber processing industry. Environmental Modeling and Assessment, 55: 401-408. DOI: 10.1023/A:1005935032014
Atagana HI, Ejechi BO and Ogodu MI (1999b) Bacteria associated with degradation of wastes from rubber processing industry. Environmental Modeling and Assessment, 59: 145-154. DOI: 10.1023/A:1006179207118

Bode HB, Kerkhoff K and Jendrossek D (2001) Bacterial degradation of natural and synthetic rubber. Biomacromolecules, 2: 295-303. DOI: $10.1021 / \mathrm{bm} 005638 \mathrm{~h}$

Boominathan M, Sundaraman M and Manhoharan C (2007) Biodiversity of microbes in dairy effluent. Pollution Research, 26: 271-276.

Buchanan RE and Gibbons NE (eds) (1984) Bergey's manual of determinative bacteriology, 8th ed. The Williams and Wilkins Co., Baltimore, USA.

Cappuccino JG and Shermann N (1999) Microbiology, a laboratory manual, 4th ed. Addison Wesley, New York, USA.

Cherian E and Jayachandran K (2009) Microbial degradation of natural rubber latex by a novel species of Bacillus sp. SBS25 isolated from soil. International Journal of Environmental Research, 3: 599-604.

Iyagba MA, Adoki A and Sokari TG (2008) Testing biological methods to treat rubber effluent. African Journal of Agricultural Research, 3: 448-454.

Kumar A, Bisht BS, Joshi VD and Dhewa T (2011) Review on bioremediation of polluted environment: A management tool. International Journal of Environmental Science, 1: 1079-1093.

Leong ST, Muttamara S and Laortanakul P (2003) Reutilization of wastewater in a rubber-based processing factory: a case study in Southern Thailand. Resources, Conservation and Recycling, 37: 159-172. DOI: 10.1016/S09213449(02)00073-3

Mahat MS and MacRae IC (1992) Rhizopus oligosporus grown on natural rubber waste serum for production of single cell protein: a preliminary study. World Journal of Microbiology and Biotechnology, 8: 63-64. DOI: 10.1007/BF01200687

Manju GN, Raji C and Anirudhan (1998) Evaluation of coconut husk carbon for the removal of arsenic from water. Water Research, 32: 3062-3070. DOI: 10.1016/S00431354(98)00068-2

Mohammadi M, Che Man H, Hassan MA and Lai Yee P (2010) Treatment of wastewater from rubber industry in Malaysia. African Journal of Biotechnology, 9: 62336243.

Monica S, Karthik L, Mythili S and Sathiavelu A (2011) Formulation of effective microbial consortia and its application for sewage treatment. Journal of Microbial and Biochemical Technology, 3: 51-55. DOI: 10.4172/19485948.1000051

Rungruang N and Babel S (2008) Treatment of natural rubber processing wastewater by combination of ozonation and activated sludge process. In: International Conference on 
Environmental Research and Technology (ICERT 2008).

Parkroyal Penang, Malaysia, 259-263.

Tariq M, Ali M and Shah Z (2006) Characteristics of industrial effluents and their possible impacts on quality of underground water. Soil and Environment, 25: 64-69.
Tekasakul P and Tekasakul S (2006) Environmental problems related to natural rubber production in Thailand. Journal of Aerosol Research, 21: 122-129.

Ye Q, Ohtake H and Toda K (1988) Phosphorus removal by pure and mixed cultures of microorganisms. Journal of Fermentation Technology, 66: 207-212. DOI: 10.1016/0385-6380(88)90049-0 